\title{
KARAKTERISTIK KIMIA SARI BUAH PEDADA (Sonneratia caseolaris) SELAMA PENYIMPANAN
}

\author{
Dini Wulan Dari, Mutia Ananda, dan Dini Junita \\ Program Studi Ilmu Gizi, Sekolah Tinggi Ilmu Kesehatan Baiturrahim Jambi \\ Email: wulandaridini62@gmail.com
}

\begin{abstract}
ABSTRAK
Buah pedada yaitu buah mangrove yang hidup di perairan payau, bagian dasar dibungkus kelopak bunga, dan tidak beracun. Masyarakat jarang mengkonsumsi langsung buah pedada karena rasanya yang asam. Buah pedada memiliki beberapa kandungan gizi yang baik untuk kesehatan, namun buah pedada belum dimanfaatkan secara optimal. Buah tersebut dapat diolah menjadi produk pangan seperti sari buah. Pengolahan dan penyimpanan dapat mempengaruhi kandungan gizi produk. Tujuan penelitian ini adalah untuk mengetahui karakteristik kimia pada sari buah pedada (Sonneratia caseolaris) selama penyimpanan. Penelitian ini terdiri atas tiga perlakuan yaitu sari buah pedada tanpa penambahan gula (P1), sari buah pedada dengan penambahan gula $60 \%(\mathrm{P} 2)$, dan sari buah pedada dengan penambahan gula 70\% (P3), sari buah yang telah diolah kemudian disimpan pada tiga waktu penyimpan (hari ke-0, ke-3 dan ke-6) pada suhu $7^{\circ} \mathrm{C}$. Pada setiap waktu penyimpanan dilakukan uji karakteristik kimia untuk mengetahui rasio kenaikan dan penurunan zat gizi dan kapsitas antioksidan yang terjadi pada sari buah pedada (sonneratia caseolaris) selama penyimpanan. Karakteristik kimia sari buah pedada selama penyimpanan 0 hari, 3 hari dan 6 hari padaa suhu $7^{\circ} \mathrm{C}$ mengalami kenaikan pada parameter kadar abu yaitu sebesar $0,02 \%$ dan serat sebesar $0,81 \%$. Kadar karbohidrat dan serat mengalami kenaikan yaitu berturut-turut sebesar $0,9 \%$ dan $0,81 \%$ serta penurunan berturut-turut sebesar $0,2 \%$ dan $0,51 \%$. Parameter yang lainnya mengalami penurunan yaitu kadar protein sebesar $0,16 \%$, vitamin C sebesar 3,27 mg dan aktivitas sebesar 0,65\%. Sari buah pedada dengan karakteristik kimia terbaik selama penyimpanan adalah pedada $200 \mathrm{~g}$ dengan penambahan gula $70 \%$.

Kata kunci-karakteristik kimia; pedada; penyimpanan; sari buah
\end{abstract}

\section{PENDAHULUAN}

Indonesia merupakan negara yang sangat kaya akan keanekaragaman hayatinya, terutama kekayaan yang ada di wilayah perairan. Kekayaan yang begitu melimpah, banyak memberikan manfaat bagi manusia. Provinsi Jambi terdapat Kabupaten Tanjung Jabung Barat yang merupakan daerah pesisir pantai memiliki kawasan ekosistem mangrove. Hutan mangrove merupakan salah satu ekosistem hutan tropis yang memiliki karakteristik yang khas, dan juga merupakan salah satu ekosistem penting di daerah pesisir/pantai. Ahmed et al., (2010) menyatakan bahwa terdapat lima spesies pohon mangrove dari genus Sonneratia, yaitu: Sonneratia alba, Sonneratia caseolaris, Sonneratia ovate, Sonneratia apetala dan Sonneratia laceolata. Tanaman ini memiliki daun berbentuk elips dan ujungnya memanjang dengan tulang daun berbentuk menjari. Buah tersebut tidak beracun dan dapat dikonsumsi secara langsung.

Buah pedada (Sonneratia caseolaris) memiliki kandungan gizi yang tinggi dan dapat dimanfaatkan sebagai sumber pangan (Septiadi, 2010). Kandungan gizi pada 100 gr buah yaitu vitamin A 221,97 IU, vitamin B 5,04 mg, vitamin B2 7,65 mg dan vitamin C 56,74 mg. Hasil analisis pada penelitian lain menunjukkan kadar proksimat pada buah pedada yaitu: kadar air (bb) 84,76\%, kadar abu (bk) 8,4\%, kadar lemak(bk) 4,82\%, kadar protein (bk) 9,21\% dan kadar karbohidrat (bk) 77,57\% (Manalu, 2011; Manalu et al, 2013). Buah pedada juga memiliki kandungan fitokimia seperti steroid, tripenoid dan flavonoid. Senyawa fitokimia seperti flavanoid merupakan antioksidan yang menetralisir radikal bebas yang menyerang sel-sel tubuh kita, radikal bebas tersebut dapat menyebabkan kanker, penyakit jantung dan penuaan dini (Ahmed et al, 2010). Buah pedada memiliki kandungan vitamin $\mathrm{C}$ yang tinggi. Vitamin $\mathrm{C}$ memiliki peran penting dalam homeostasis sel, bertindak sebagai antioksidan kuat serta modulator positif diferensiasi sel (Daniel et al, 2013). Buah pedada berpotensi sebagai antioksidan dan juga memiliki kandungan gizi yang tinggi (Ramadani et al. 2020). Antioksidan adalah senyawa yang memiliki peranan penting dalam menjaga kesehatan karena dapat menangkap molekul radikal bebas sehingga menghambat reaksi oksidatif dalam tubuh yang 
merupakan penyebab berbagai penyakit (Adawiyah et al, 2015).

Dalam pengolahan sari buah terdapat penambahan gula, penambahan gula dilakukan karena gula mudah larut dalam air, dimana semakin tinggi suhu maka tingkat kelarutan semakin besar. Gula dapat berguna sebagai pengawet alami, selain itu gula pasir berperan dalam memperbaiki cita rasa dan aroma dengan cara membentuk keseimbangan antara rasa asam, rasa pahit dan rasa asin (Ramadani $e t$ al., 2019).

Buah pedada dapat dimanfaatkan secara maksimal dengan pengolahan yang tepat. Salah satu alternatif pada pengolahan buah pedada yaitu dengan dijadikan sari buah ataupun produk lainnya seperti yang sudah diteliti oleh Dari et al. (2020) menjadi produk permen jelly. Berdasarkan SNI (2014), sari buah adalah cairan yang dihasilkan dari pemerasan atau penghancuran buah segar yang telah masak. Sari buah adalah cairan jernih atau agak jernih, tidak difermentasi, diperoleh dari hasil pengepresan buah-buahan yang telah matang dan masih segar.

Pembuatan sari buah bertujuan untuk meningkatkan daya simpan serta nilai tambah dari buahbuahan. Namun penyimpanan yang tidak tepat dapat menyebabkan degradasi vitamin pada sari buah. Kerusakan yang dapat terjadi adalah reaksi oksidasi, baik selama proses pengolahan maupun penyimpanan. Degradasi vitamin pada sari buah sangat dipengaruhi oleh suhu penyimpanan. Menurut Rahmawati (2010) cara yang paling efektif untuk menurunkan laju degradasi sari buah adalah dengan menurunkan suhu produk atau melakukan pendinginan dengan suhu rendah.

Olahan sari buah pedada dapat dimanfaatkan sebagai minuman sari buah yang bernilai ekonomis, bergizi dan mudah didapatkan terutama di Kecamatan Kuala Tungkal Kabupaten Tanjung Jabung Barat Provinsi Jambi, sehingga sari buah pedada dapat diperkenalkan sebagai inovasi produk lokal yang baru. Berdasarkan uraian di atas, penelitian ini bertujuan untuk mengetahui karakteristik kimia pada sari buah pedada (Sonneratia caseolaris) selama penyimpanan 0 hari, 3 hari dan 6 hari pada suhu $7^{0} \mathrm{C}$ dengan penambahan gula bervariasi yaitu $0 \%, 60 \%$ dan $70 \%$

\section{METODOLOGI PENELITIAN}

\section{A. Bahan dan Alat}

Bahan yang digunakan dalam penelitian ini adalah gula pasir dan buah pedada (sonneratia caseolaris) yang sudah tua/matang yang diambil dari Kuala Tungkal Kabupaten Tanjung Jabung Barat, Provinsi Jambi. Berat buah pedada yang digunakan di masing-masing perlakuan yaitu $200 \mathrm{~g}$. Bahan kimia yang digunakan adalah katalis campuran, $\mathrm{H}_{2} \mathrm{SO}_{4}$ pekat, $\mathrm{H}_{2} \mathrm{SO}_{4} 0,3 \mathrm{~N}, \mathrm{NaOH} 40 \%, \mathrm{NaOH}$ $0,3 \mathrm{~N}$, indikator campuran, $\mathrm{NaOH}$ 1,5 N, aseton, Hcl $1 \mathrm{ml}$, amilum $1 \mathrm{ml}$, aquades, larutan Iod $0.01 \mathrm{~N}$, larutan $\mathrm{DPPH}$, methanol. Alat yang digunakan adalah eksikator, oven $105^{\circ} \mathrm{C}$, pemanas listrik, pompa vakum, spektrofotometer.

\section{B. Prosedur Percobaan}

Formulasi sari buah pedada mengacu pada penelitian Meilina (2019) berdasarkan pengujian sensori yang sudah dilakukannya, didapatkan formula terpilih untuk dilanjutkan ke penelitian ini, yaitu P1: Pedada $200 \mathrm{~g}$ dengan penambahan gula 0\%; P2: Pedada $200 \mathrm{~g}$ dengan penambahan gula 60\%; P3: Pedada $200 \mathrm{~g}$ dengan penambahan gula $70 \%$. Buah pedada yang telah diolah menjadi sari buah pedada disimpan pada suhu yang dingin yaitu suhu $7^{\circ} \mathrm{C}$ selama 0 hari, 3 hari dan 6 hari. Sari buah pedada hanya menggunakan tambahan gula pasir dan tanpa penambahan bahan tambahan lain, sehingga untuk penyimpanan yang tepat pada suhu $7^{\circ} \mathrm{C}$ dan diamati pada penyimpanan hari ke- 0 , hari ke 3 dan hari ke-6 mengacu kepada Wariyah (2010). Sari buah yang sudah sesuai perlakuan kemudian dilakukan analisis karakteristik kimia yaitu penentuan kadar abu (AOAC, 1980), protein (AOAC, 1980), lemak (AOAC, 1984), karbohidrat (by difference), serat (AOAC, 1984), vitamin C (metode iodometri, SNI 1992), dan aktivitas antioksidan (metode DPPH, Rekha et al., 2012). Pengujian dilakukan sebanyak dua kali pengulangan dan secara duplo. Dari data yang diperoleh kemudian dilakukan analisis data secara deskriptif untuk semua parameter uji.

\section{Analisis Data}

Pengolahan data menggunakan software Microsoft Excel. Data yang diperoleh kemudian diolah dengan analisis data secara deskriptif. Hasil analisis ini bertujuan untuk mengetahui karakteristik kimia minuman sari buah pedada dengan penambahan gula yang berbeda yang disimpan 
pada suhu $7^{\circ} \mathrm{C}$ selama 0 hari, 3 hari dan 6 hari yang meliputi karbohidrat, protein, serat, air, abu, vitamin c dan aktivitas antioksidan.

\section{HASIL DAN PEMBAHASAN}

\section{A. Karakteristik Kimia pada Sari Buah Pedada Selama Penyimpanan}

Berdasarkan hasil uji kadar proksimat pada sari buah pedada selama penyimpanan, diperoleh hasil sebagai berikut:

\section{Karbohidrat}

Gambar 1 menunjukkan bahwa kadar karbohidrat akan meningkat seiring dengan penambahan gula, hal ini dikarenakan gula merupakan komponen penyusun karbohidrat sehingga mengakibatkan semakin banyak penambahan gula yang ditambahkan pada sari buah pedada maka akan semakin banyak karbohidrat yang terkandung dalam sari buah tersebut.

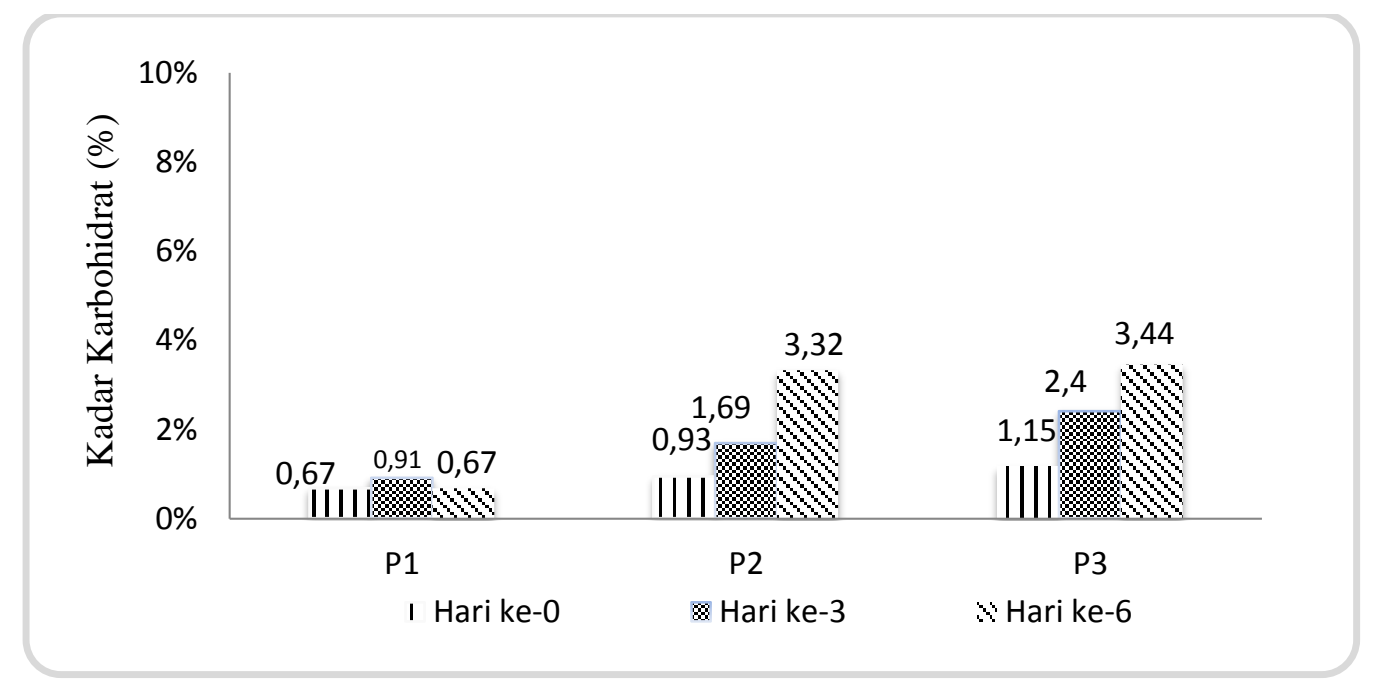

Gambar 1. Grafik Kadar Karbohidrat Pada Sari Buah Pedada Selama Penyimpanan

Kadar karbohidrat sari buah pedada selama penyimpanan mengalami peningkatan terutama pada P2 dan P3. Peningkatan selama penyimpanan dipengaruhi oleh penambahan konsentrasi gula. Hal tersebut sejalan dengan hasil penelitian dari Asgar dan Rahayu yang menyimpulkan bahwa gula yang terakumulasi selama penyimpanan di suhu dingin dapat dirombak menjadi pati dan terjadi peningkatan proses respirasi dan transpirasi selama penyimpanan (Asgar et al, 2014).

\section{Protein}

Gambar 2 pada parameter uji protein dapat dilihat bahwa semakin lama penyimpanan, maka kadar protein pada sari buah pedada semakin menurun. Penurunan protein selama penyimpanan pada P1 secara berturut-turut sebesar $0.04 \%-0.11 \%$, untuk P2 mengalami penurunan protein sebesar $0.22 \%$, dan pada $\mathrm{P} 3$ mengalami penurunan protein sebesar $0.05 \%-0.33 \%$.

Degradasi protein pada produk minuman yang diinokulasi dengan protease pada waktu penyimpanan menunjukkan bahwa semakin lama waktu penyimpanan, maka semakin tinggi degradasi protease yang terjadi. Selama proses penyimpanan, protein mengalami denaturasi dan degradasi yaitu pemecahan molekul kompleks menjadi molekul yang lebih sederhana. Proses degradasi protein disebabkan oleh aktivitas enzim proteolitik yang berperan aktif dalam proses denaturasi protein. Enzim proteolitik ini akan teraktivasi pada $\mathrm{pH}$ rendah sehingga dengan terbentuknya $\mathrm{pH}$ rendah protein semakin mudah terdegradasi (Khusniati dan Yantyati, 2010). Berdasarkan teori diatas dapat disimpulkan bahwa dengan adanya degradasi protein, menyebabkan protein pada sari buah pedada menjadi berkurang seiring dengan lamanya waktu penyimpanan 


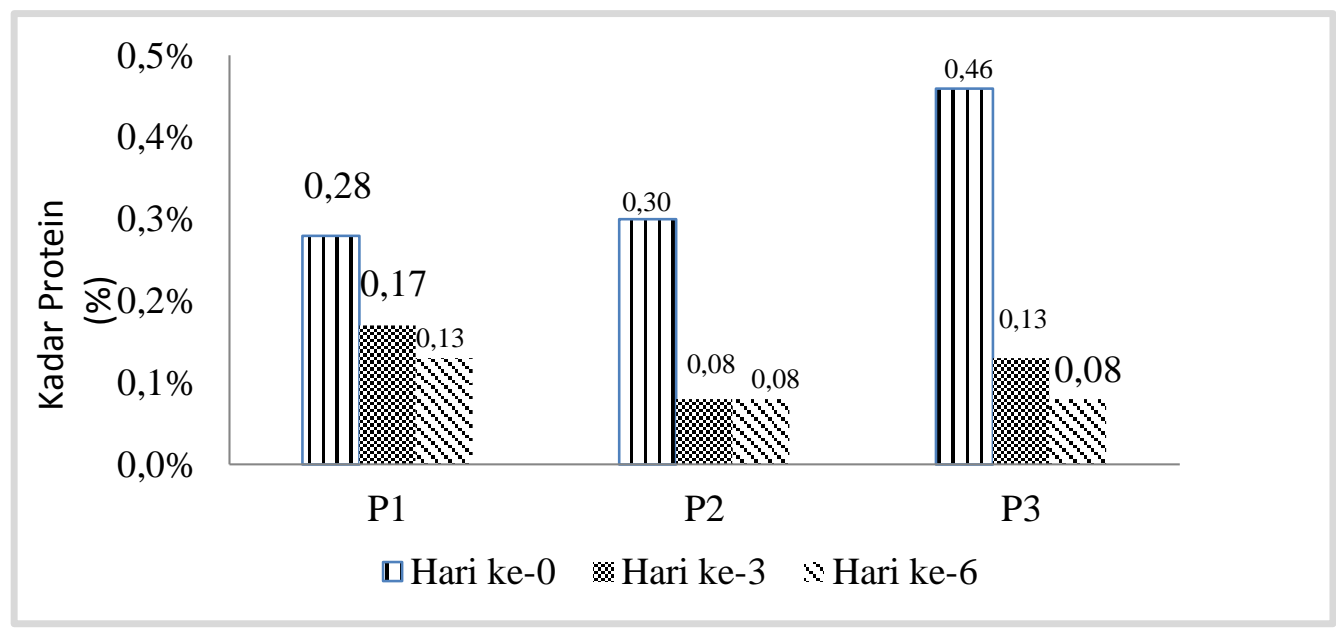

Gambar 2. Grafik Kadar Protein Pada Sari Buah Pedada Selama Penyimpanan

\section{Kadar Abu}

Berdasarkan Tabel 1 dapat diketahui bahwa kadar abu dalam sari buah pedada akan semakin bertambah selama penyimpanan. Pada gambar dibawah dapat dilihat bahwa di hari ke-0 kadar abu pada P1 lebih besar dari P2 dan P3. Hal ini menunjukan bahwa penggunaan rasio gula mempengaruhi kandungan mineral sari buah pedada.

Tabel 1. Kadar Abu Sari Buah Pedada Selama Penyimpanan

\begin{tabular}{cccc}
\hline \multirow{2}{*}{ Sampel } & \multicolumn{3}{c}{ Kadar abu selama penyimpanan $(\%)$} \\
\cline { 2 - 4 } & Hari ke-0 & Hari ke-3 & Hari ke-6 \\
\hline P1 & 0,06 & 0,07 & 0,09 \\
P2 & 0,04 & 0,05 & 0,07 \\
P3 & 0,04 & 0,04 & 0,08 \\
\hline
\end{tabular}

keterangan: P1: Pedada $200 \mathrm{~g}$ dengan penambahan gula $0 \%$; P2: Pedada $200 \mathrm{~g}$ dengan penambahan gula $60 \%$; P3: Pedada 200 g dengan penambahan gula $70 \%$

Penelitian yang dilakukan Ramadani et al (2019), menunjukan bahwa sirup buah pedada dengan penambahan gula $0 \%$ mengandung kadar abu sebesar $0.32 \%$ sedangkan sirup buah pedada dengan konsentrasi gula 70\% mengandung kadar abu sebesar $0.04 \%$. Pada setiap perlakuan kadar abu terus meningkat seiring bertambahnya waktu penyimpanan. Peningkatan kadar abu pada sari buah pedada disebabkan oleh penurunan beberapa zat gizi selama penyimpanan. Dari hasil penelitian Kusumaningrum et al, (2017) terkait penurunan kadar abu pada produk jenang dipengaruhi oleh kenaikan protein selama penyimpanan. Konsentrasi air juga berpengaruh pada peningkatan kadar abu, Semakin banyak air yang terikat dapat meningkatkan kandungan abu karena didalam air juga terkandung banyak garam-garam mineral, seperti $\mathrm{Ca}, \mathrm{Na}, \mathrm{K}$, dan $\mathrm{Cl}$.

\section{Serat}

Berdasarkan Gambar 3 dapat dilihat bahwa kadar serat yang terdapat pada sari buah pedada pada setiap perlakuan mengalami kenaikan yang cukup tinggi pada hari ke-3 terutama pada konsentrasi penambahan gula yang lebih besar. Kemudian pada hari ke-6 kadar serat pada P1 tetap dan pada P2 dan P3 mengalami penurunan. Peningkatan serat yang terjadi pada hari ke-3 dan penurunan kembali pada hari ke-6 dipengaruhi oleh hidrolisis, hidrolisis adalah proses peruraian suatu senyawa oleh air. Proses tersebut dapat terjadi dalam suasana asam, basa, atau netral tergantung pada senyawa yang bereaksi serta karena enzim. Hidrolisis selulosa merupakan suatu proses yang dilakukan untuk menghasilkan glukosa. Hidrolisis selulosa dilakukan dengan penambahan asam atau secara enzimatis, (Harianja et al, 2015). 


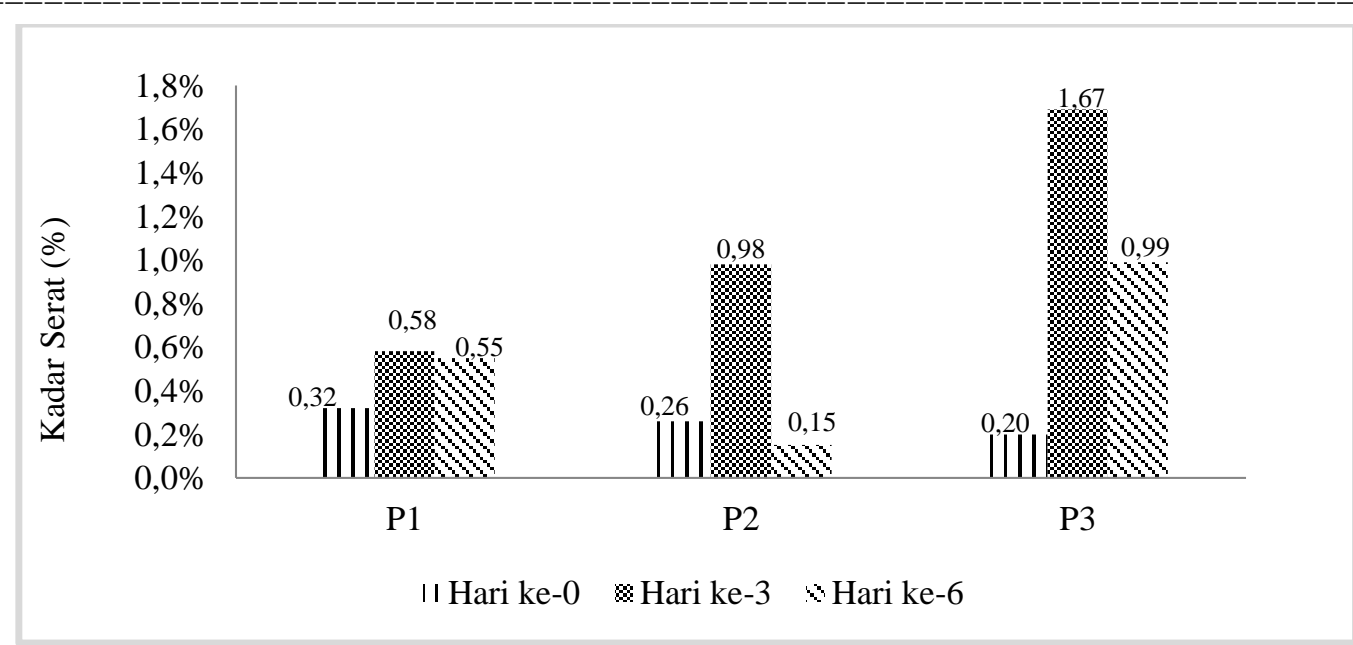

Gambar 3. Grafik Kadar Serat Pada Sari Buah Pedada Selama Penyimpanan

\section{Kadar Vitamin C pada Sari Buah Pedada Selama Penyimpanan}

Hasil analisis vitamin C sari buah pedada selama penyimpanan disajikan pada Gambar 4. Data yang didapatkan menunjukkan telah terjadi degradasi kadar vitamin $\mathrm{C}$ pada sari buah pedada selama penyimpanan. Dimana perlakuan P1 mengalami penurunan rata-rata sebesar 4,17 mg. P2 mengalami penurunan rata-rata sebesar 2,7 mg dan P3 mengalami penurunan rata-rata sebesar 2,9 mg. Terjadi perbedaan yang jelas antara penurunan kadar vitamin $\mathrm{C}$ pada sari buah tanpa penambahan gula dan sari buah dengan penambahan gula. pada hari ke-0 P1 memiliki kadar vitamin $\mathrm{C}$ yang lebih besar dari P2 dan P3, namun pada hari ke-3 dan hari ke-6 P1 mengalami degradasi vitamin C yang cukup besar, berbeda dengan P2, dan P3 dimana pada hari ke-0 sudah mengalami degrasi yang besar namun pada hari ke-3 dan ke-6 degradasi terjadi tidak terlalu besar.

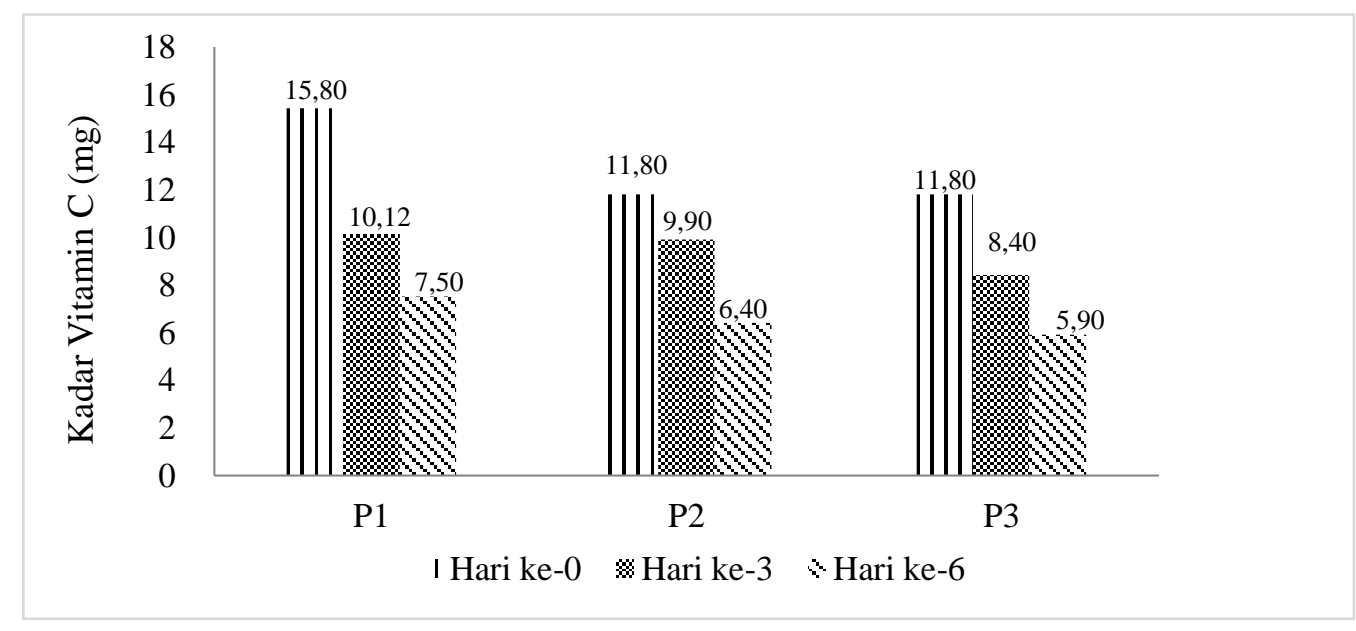

Gambar 4. Grafik Kadar Vitamin C Pada Sari Buah Pedada Selama Penyimpanan

Perbedaan degradasi vitamin C pada P1, P2 dan P3 disebabkan oleh beberapa faktor, salah satunnya karena faktor penambahan gula dan air saat proses pengolahan. Herbig et al, (2017) mengatakan bahwa Vitamin $\mathrm{C}$ dapat teroksidasi menjadi asam dehidroaskorbat kemudian mengalami hidrolisis menjadi asam diketoglutanat dalam air. Oleh karena itu, semakin besar kandungan airnya, maka Vitamin C akan semakin mudah terdegradasi. Hasil penelitian yang telah dilakukan Devianti dan Whardani, (2018) menyimpulkan bahwa Sampel dengan penambahan gula mengalami penurunan vitamin C yang lebih lambat dibandingkan sampel tanpa penambahan gula. Laili et al,. (2017) menyatakan hal itu disebabkan karena Penambahan gula dapat melindungi kandungan vitamin $\mathrm{C}$, gula menyebabkan minuman menjadi lebih pekat. Octaviani et al, (2014) menambahkan akan tetapi penambahan gula yang berlebihan justru dapat menurunkan kandungan vitamin $\mathrm{C}$ di dalam sari buah tersebut 


\section{Aktivitas Antioksidan pada Sari Buah Pedada Selama Penyimpanan}

Dari hasil analisis aktivitas antioksidan pada sari buah pedada selama penyimpanan dapat diketahui bahwa sari buah pedada memiliki aktivitas antioksidan yang sangat tinggi, dimana nilai rata-rata \% inhibisi yaitu diatas $80 \%$. Hal ini sama dengan penjelasan dari Kusuma (2012) yang menyatakan bahwa secara spesifik dikatakan suatu senyawa mempunyai aktivitas antioksidan sangat kuat jika mampu menghambat perkembangan radikal bebas lebih dari $80 \%$. Dikatakan sedang jika mampu menghambat sebesar 50\%-80\%. Dan dikatakan lemah jika mempunyai kemampuan penghambatan kurang dari $50 \%$.

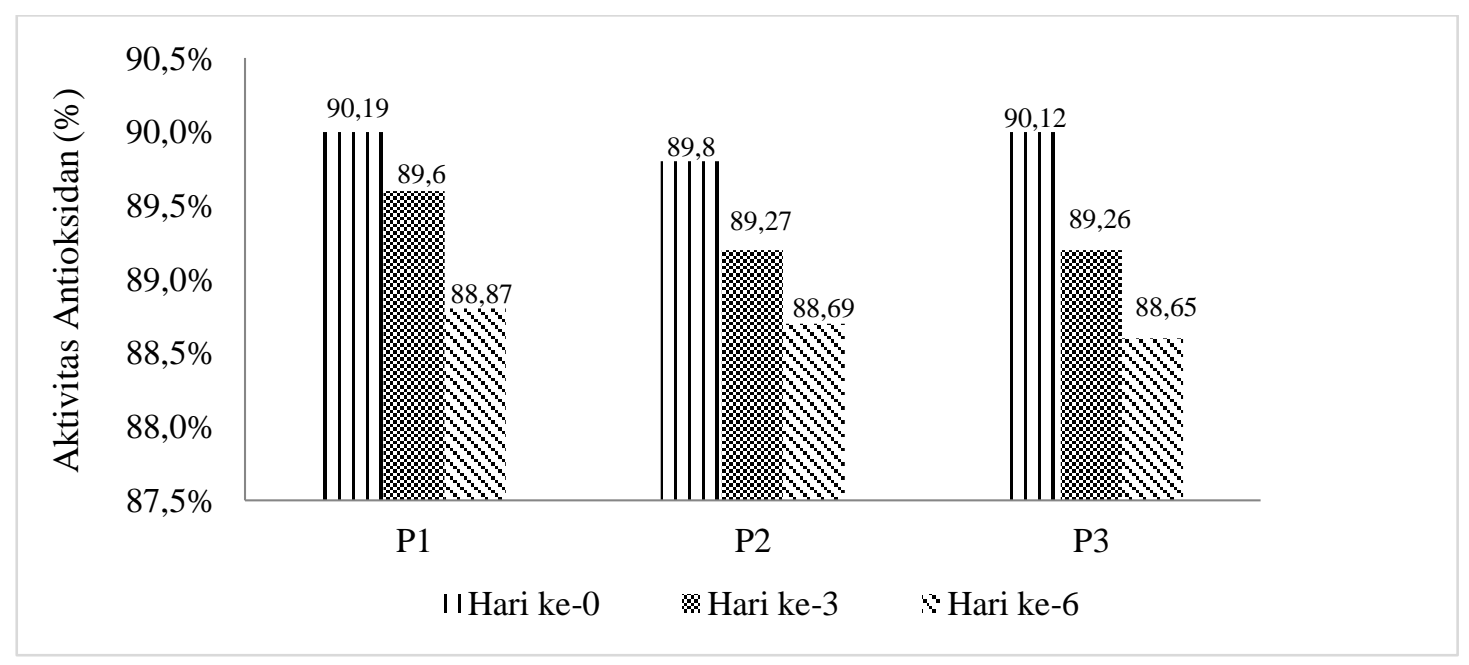

Gambar 5. Grafik Aktivitas Antioksidan Pada Sari Buah Pedada Selama Penyimpanan

Sampel P1 mengalami penuunan aktivitas antioksidan sebesar 1,2\%. P2 mengalami penurunan aktivitas antioksidan sebesar $1.3 \%$. dan P3 mengalami penurunan aktivitas antioksidan sebesar $1.4 \%$. Rendahnya penurunan aktivitas antioksidan pada P1 disebabkan karena tidak adanya penambahan gula. Hal ini didukung oleh Octaviani et al (2014), pada penelitiannya menunjukan bahwa semakin tinggi kadar gula, maka nilai aktivitas antioksidan pada sari buah buni semakin rendah.

Rendahnya penurunan aktivitas antioksidan pada sari buah pedada selama penyimpanan juga disebabkan oleh penempatan suhu penyimpanan yang baik dimana sari buah disimpan dalam suhu kulkas $5^{\circ}-10^{\circ} \mathrm{C}$. Hal ini sejalan dengan penelitian yang telah dilakukan Rohadi (2013) yang menyatakan bahwa Aktivitas antioksidan minuman madu-galohgor pada kedua jenis perlakuan suhu penyimpanan memiliki kecenderungan turun selama penyimpanan. Namun penyimpanan pada suhu ruang menunjukkan penurunan antioksidan yang lebih besar dibandingkan dengan penyimpanan pada suhu dingin. Berkurangnya aktivitas antioksidan dapat dikarenakan terjadinya proses oksidasi selama penyimpanan. Namun Pengurangan aktivitas antioksidan pada suhu dingin terjadi lebih lambat dibandingkan pada suhu ruang.

\section{KESIMPULAN}

Karakterisktik kimia sari buah pedada untuk parameter karbohidrat paling tinggi terdapat pada sampel P3 penyimpanan hari ke-6 yaitu 3,44\%. Kadar protein paling tinggi terdapat pada sampel P3 penyimpanan hari ke-0 yaitu $0,46 \%$. Kadar abu paling tinggi terdapat pada sampel P1 penyimpanan hari ke-6 yaitu 0,09\%. Kadar serat paling tinggi terdapat pada sampel $\mathrm{P} 3$ penyimpanan hari ke-3 yaitu 1,67\% . Kadar vitamin C paling tinggi terdapat pada sampel P1 penyimpanan hari ke-0 yaitu 15,80 mg. Aktivitas antioksidan paling tinggi terdapat pada sampel P1 penyimpanan hari ke-0 yaitu 90,19\%.

\section{DAFTAR PUSTAKA}

Adawiyah, Sukandar, Muawanah. 2015. Aktivitas Antioksidan dan Kandungan Komponen Bioaktif Sari Buah Namnam. Jurnal Kimia VALENSI. 1(2): 130-136. doi:10.15408/jkv.v0i0.3155. 
Ahmed R., S.J, Moushumi, Ahmed, Ali, Haq Rahmatullah. 2010. Serum Glucose And Lipid Profiles In Rats Following Administration Of Sonneratia Caseolaris. Engl. (Sonneratia Rear) Leaf Powder In Diet. Advances in Natural and Applied Sciences. 4(2): 171-173. ISSN 1995-0772.

Daniel, S,. Jorje, O,. Marcela, L,. Francisco, N,. Sylvain, M,. Nelson, O,. \& Juan, P, H,. 2013. The vitamin C transporter SVCT2 is down-regulated during postnatal development of slow skeletal muscles. Histochemistry and cell Biology. 139(6):887-894. doi: 10.1007/s00418-012-1075-4.

Dari DW, Ramadani DT, Aisah A. 2020. Kandungan Gizi dan Aktivitas Antioksidan Permen Jelly Buah Pedada (Sonneratia caseolaris) dengan Penambahan Karagenan. 9(2): 154-165. doi: 10.36565/jab.v9i2.153

Devianti, Wardhani. 2018. Degradasi Vitamin C Dalam Jus Buah Dengan Penambahan Sukrosa dan Lama Waktu Konsumsi. Journal of Research and Technology. 4(1): 41-46. P-ISSN: 2460 - 5972, E-ISSN: $2477-6165$.

Harianja JW, Idiawati N , Rudiyansyah. 2015. Optimasi Jenis dan Konsentrasi Asam pada Hidrolisis Selulosa Dalam Tongkol Jagung. JKK. 4(4):66-71. ISSN 2303-1077.

Herbig Anna-Lena, Catherine Renard. Factors that Impact The Stability of Vitamin C at Intermediate Temperatures in a Food Matrix. Food Chemistry, Elsevier. 220: 444-451. doi: 10.1016/j.foodchem.2016.10.012

Kusuma, R.A. 2012. Aktifitas Antioksidan Buah Takokak (Solanum torvum Swartz) [Skripsi]. Fakultas Teknologi Pertanian. Institut Pertanian Bogor. Bogor.

Kusumaningrum A, Ariani D, Khasanah Y, WiyonoT . 2017. Pengaruh Waktu Penyimpanan Terhadap Karakteristik Makanan Tradisional "Jenang Saban". Jurnal Penelitian Teknologi Industri. 9(1): 23-36. ISSN : 2085-580X

Laili, Miftahul., Alimuddin., dan Erwin. 2017. Penetapan Kadar Vitamin C dalam Sirup Buah Naga Merah (Hylocereus polyrhizus) dengan Variasi Waktu Penyimpanan. Jurnal Atomik. 2(1): 128 133. e-ISSN 2549-0052.

Manalu RDE, Salamah E, Retiaty F, Kurniawati N. 2013. Kandungan Zat Gizi Makro dan Vitamin Produk Buah Pedada (Sonneratia caseolaris). Penelitian Gizi dan Makanan . 36 (2):135-140. pISSN: 0125-9717.

Manalu, RDE. 2011. Kadar beberapa vitamin pada buah Pedada (Sonneratia caseolaris) dan hasil olahannya. [Skripsi]. Departemen Teknologi Hasil Perairan Fakultas Perairan dan Ilmu Kelautan. Institut Pertanian Bogor. Bogor

Mazrouh MM. 2015. Effects of freezing storage on the biochemical composition in muscles of Saurida undosquamis (Richardson 1848) comparing with imported frozen. International Journal of Fisheries. 3(2): 295-299. Online ISSN: 2347-5129.

Octaviani, L.F., Rahayuni, A. 2014. Pengaruh Berbagai Konsentrasi Gula terhadap Aktivitas Antioksidan dan Tingkat Penerimaan Sari Buah Buni (Antidesma bunius). Journal of Nutrition College, 3(4):958 - 965. doi:10.14710/jnc.v3i4.6916.

Rahmawati, Maulida, 2010. Pengemasan Pada Buah sebagai Upaya Memperpanjang Umur Simpan dan Kajian Sifat Fisiknya selama Penyimpanan. Jurnal Teknologi Pertanian. 6(2): 45-49.

Ramadani DT, Dari DW, Aisah A. 2020. Daya terima permen jelly buah pedada (sonneratia caseolaris) dengan penambahan karagenan. Jurnal Akademika Baiturrahim. 9(1): 15-24.

Ramadani DT, Meilina M, Arsita Y, Dari DW, Safitri N. 2019. Pengaruh Penambahan Gula Terhadap Karakterisitik Kimia Sirup Pedada (Sonneratia Caseolaris). Prosiding S1 Ilmu Gizi STIKes Baiturrahim Jambi.

Rekha C, Poornima G, Manasa M, Abhipsa V, Devi JP, Kumar HTV, Kekuda TRP. 2012. Ascorbic acid, total phenol content and antioxidant activity of fresh juice of four ripe and unripe citrus fruits. Chemical Science Transactions. 1(2): 303-310.

Rohadi. 2013. Umur Simpan, Aktivitas Antioksidan dan Keamanan Minuman Madu-Galohgor [Thesis]. Institut Pertanian Bogor. Bogor.

Standar Nasional Indonesia. 2014. Minuman Sari Buah. Badan Standarisasi Nasional Indonesia. Jakarta.

Wariyah C. 2010. Vitamin c retention and acceptability of orange (citrus nobilis var. microcarpa) juice during storage in refrigerator. Jurnal AgriSains. 1(1): 50-55 